China Perspectives

58 | march - april 2005

Varia

\title{
China's Drive to Revitalise the Northeast
}

\section{Dong Lisheng}

\section{OpenEdition}

Journals

Édition électronique

URL : http://journals.openedition.org/chinaperspectives/462

DOI : 10.4000/chinaperspectives.462

ISSN : 1996-4617

\section{Éditeur}

Centre d'étude français sur la Chine contemporaine

\section{Édition imprimée}

Date de publication : 1 avril 2005

ISSN : 2070-3449

\section{Référence électronique}

Dong Lisheng, "China's Drive to Revitalise the Northeast », China Perspectives [En ligne], 58 | march april 2005, mis en ligne le 01 avril 2008, consulté le 28 octobre 2019. URL : http://

journals.openedition.org/chinaperspectives/462 ; DOI : 10.4000/chinaperspectives.462

Ce document a été généré automatiquement le 28 octobre 2019

(c) All rights reserved 


\title{
China's Drive to Revitalise the Northeast
}

\author{
Dong Lisheng
}

1 In August 2003, the Chinese government announced that it had made "the revitalisation of the traditional industrial bases in the northeast" (WW, Dongbei) a state policy, on a par with the policy of developing the western region of the country ${ }^{1}$. However the policies for these two areas have been drawn up from different backgrounds and local situations and with different goals in mind. In the west the emphasis is on the elimination of poverty. Accordingly, the preferential policies of the central government are directed at increasing the funding level of the central financial resources earmarked for the western region; to favour infrastructure projects, including irrigation and hydro-power, transportation and energy; to increase transfer payments to the region; to increase the availability and accessibility of banking and loan support ${ }^{2}$.

2 The northeast is China's traditional industrial base and has a higher level of economic development than the west. The revitalisation aims are to increase the wealth of the region and achieve its industrialisation quickly. It is hoped that the northeast will become a new pillar of the national economy, after the Yangtse River Delta, Pearl River Delta and the pan-Bohai area ${ }^{3}$.

3 The State Council has set up a leading group in charge of the new drive. Premier Wen Jiabao chairs this group with two vice-premiers as deputy heads: Huang Ju, concurrently a member of the Politburo Standing Committee, and Zeng Peiyan, also a Politburo member. Some 25 ministers also serve as members of the group ${ }^{4}$. Its general office is headed by Zhang Guobao, Vice-Minister of the State Development and Reform Commission. The office, which carries a ministerial rank, has a total of 24 staff members in four divisions for overall co-ordination, policy and institutions, manufacturing industry, and other related industries.

4 Premier Wen Jiabao went on inspection tours to Liaoning province in late May and early June, and to Heilongjiang and Jilin provinces in early August, 2003. During the latter visit, he said rejuvenating the traditional industrial bases in the northeast and 
turn them into national or international bases for the manufacture of equipment and important raw materials was a historic task.

This article will first review the dire situation in the industrial and agricultural sectors in the region in the last decade. This will be followed by an analysis of the strategy of the new drive centred on redefining the government's role and allowing the market mechanism to play a greater role in the region's rejuvenation. The new policies include the designation of the northeast as an experimental region for delegating examination and approval power for investments by non-state enterprises and foreign businessmen, new projects and land-use rights; implementation of VAT reforms; abolition of agricultural taxes; and increasing the central government's contribution to the region's pension and unemployment funds. It then highlights the initiatives of the three provincial governments in the region, before investment opportunities to overseas investors are considered.

An ailing region

6 The region was once dubbed "the industrial cradle of new China". The major industrial projects in the iron and steel, energy, heavy machinery, vehicle and aeroplane manufacturing, ship-building, and weapons sectors were the foundation of China's industrialisation. These advantages are not possessed by the coastal areas in the southeast. But efforts so far have failed to turn the potential into real productive force.

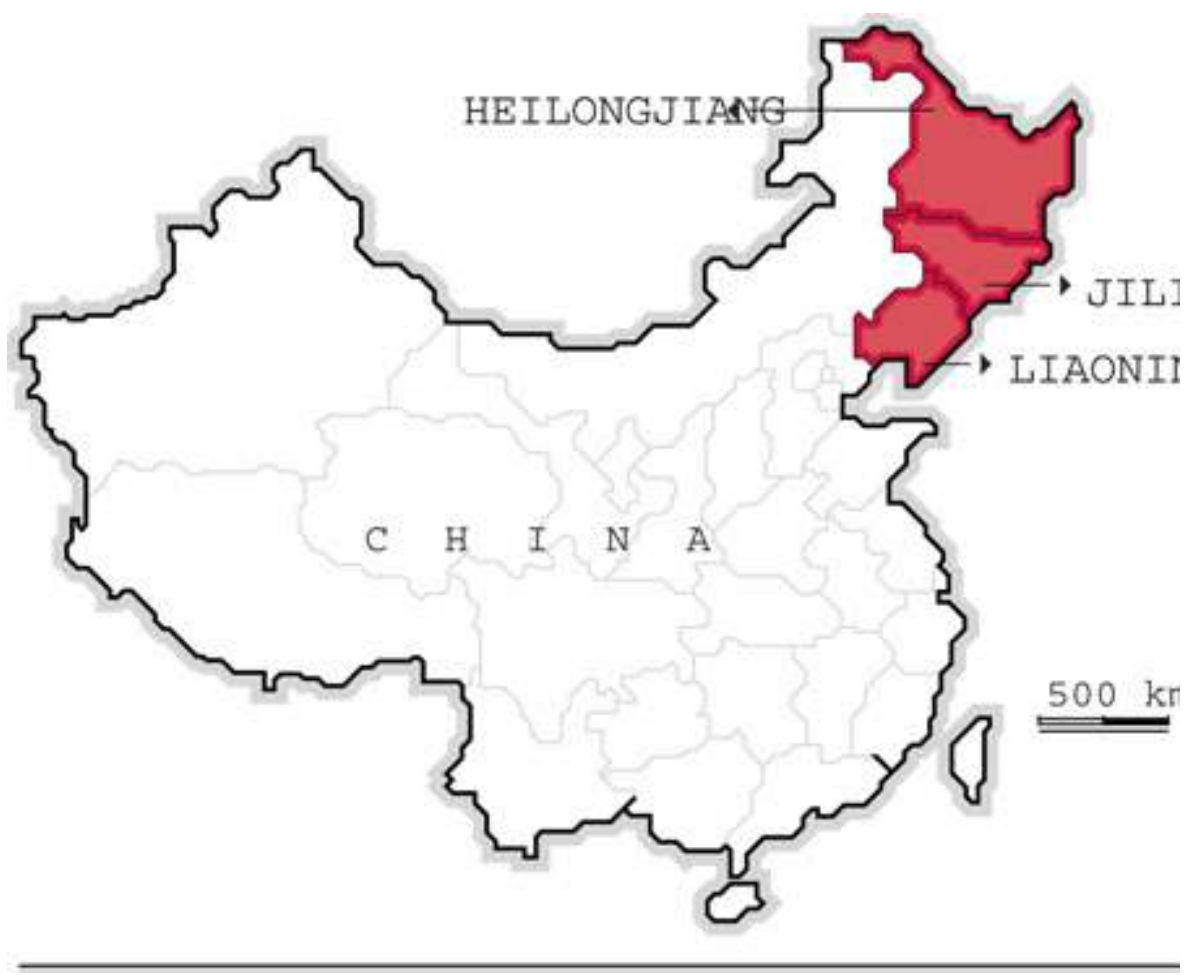

7 Some economists note that one reason why the Chinese government has decided to implement the policy of reviving the northeast is to respond to the challenges China faces after joining the World Trade Organisation (WTO). Today the industrial enterprises in this region enjoy no advantages in exporting, and their domestic market is shrinking as industry is low-tech and capital-intensive with weak international competitiveness. 
2. The economic structure of the Northeast

\begin{tabular}{|c|c|c|c|}
\hline & $\begin{array}{l}\text { Agriculture } \\
\text { Agricus }\end{array}$ & $\begin{array}{l}\text { and } \\
\text { Industry }\end{array}$ & $\begin{array}{l}\text { Service } \\
\text { Servicis }\end{array}$ \\
\hline & $1998: 2002$ & $1998: 2002$ & $1998: 2002$ \\
\hline Liaoning & 13.6910 .8 & 47.7947 .8 & 38.5241 .4 \\
\hline Jilin & 27.5719 .9 & $38.3443,5$ & 34.0936 .6 \\
\hline Heilongji & ialreg. 3511.6 & 53.1855 .6 & $30.4732 . \varepsilon$ \\
\hline Northeast & $t 17.2112 .8$ & 47.8749 .6 & 34.9237. \\
\hline China & 17.6915 .3 & 46.8951 .0 & 35.4233 .5 \\
\hline
\end{tabular}

8 The source of the region's problems can be traced back more than a decade. In the early 1990s, the protracted sluggish economy of the region was diagnosed as the "northeast syndrome" (dongbei xianxiang). The region found it very hard to adapt to structural reforms and the country's economic transition. Enterprise efficiency and market share dropped sharply. The central government provided some support but this proved ineffective due to fundamental institutional and structural problems.

3. The northeast contribution to the Chinese economy

\section{$\%$ of the corresponding national sectors}

\begin{tabular}{|c|c|c|c|c|c|c|}
\hline & $\begin{array}{r}\text { Agri } \\
\text { a }\end{array}$ & $\begin{array}{l}\text { cultu } \\
\text { cul }\end{array}$ & Ind & $\begin{array}{l}\text { त } \\
\text { lustry }\end{array}$ & & $\begin{array}{l}\text { 맘 } \\
\text { vice }\end{array}$ \\
\hline & 1998 & 2002 & 1998 & 2002 & 1998 & $200=$ \\
\hline Liaoning & 3.57 & 3.66 & 4.81 & 4.87 & 5.10 & 6.4 \\
\hline Jilin & 2.89 & 2.77 & 1.55 & 1.83 & 1.81 & 2.34 \\
\hline Heilongji & iaBg 11 & 2.77 & 3.90 & 4.05 & 2.94 & 3.60 \\
\hline Northeast & t 9.58 & 9.20 & $10.2 \dot{\phi}$ & 10.7 & 9.85 & $12 . \Sigma$ \\
\hline China & 100 & 100 & 100 & 100 & 100 & 100 \\
\hline
\end{tabular}

9 While the problems in the industrial sector remained until 2003, the region was baffled by a glut of traditionally well-marketed agricultural produce, a slow-down in the 
increase in farmers' income and stagnation of agricultural efficiency. The Xinhua News Agency termed the situation the "new northeast syndrome" (xin dongbei xianxiang). Facing foreign competition in an ever-integrated international market, the low competitiveness and high cost of the region's agricultural products became evident. As a result, the region suffered one failure after another in marketing produce that had held the sway of the domestic market under the planning system.

Unsynchronised development

In recent years, the percentage of agriculture in the region's total GDP decreased while manufacturing and services saw an increase (Tables 2 and 3) Apparently, this trend is in line with economic theory and history. Yet it is not a reflection of co-ordinated development or purposeful structural adjustment. The percentage of agriculture in the region's total GDP decreased from $17.21 \%$ in 1998 to $12.80 \%$ in 2002, a rate of 1.49 times higher than the national average ${ }^{5}$. In 1998, the region's agricultural increased value made up $9.58 \%$ of the nation's total while in 2002 this figure decreased to $9.20 \%$. This is out of the proportion of the rich agricultural resources that the region is enjoys.

In the same period, the percentage of the industrial sector's increased value rose in the region's total GDP. But the pace was slower than nationally. Of the agriculture, industry and services sectors, only the latter saw a reasonable increase, meaning its percentage of total GDP increase was accompanied by an increased percentage value for the region's service sector in the national total.

Industries' ability to absorb employment is weakening

12 From 1993 to 2002, the number of workers and employees in China increased from 602.2 million to 737.40 million. The ratio of the workforce to the total population increased from $50.81 \%$ to $57.41 \%$. In comparison, these figures have decreased in the northeast and the pace of decrease accelerated after 1999 (Table 4). If calculated with the 1993 percentage of the workforce in the region's total population, in 2001 the region should have had 48.84 million workers and employees. But the actual figure was 45.22 million, meaning there were 3.62 million more unemployed in 2001. If using the national figure of employed in the total population in 2001, in the same year the region should have had 61.2 million workers and employees. The actual shortfall was 15.99 million. The unemployment situation in the region is serious, with implications of a heavier burden on government finance to support state-owned enterprises (SOEs) in difficulty, and a lower social consumption rate. 
4. Active population figures for the northeast

\begin{tabular}{|c|c|c|c|c|}
\hline & & & \\
\hline & & 1993 & 1998 & 2002 \\
\hline \multirow{3}{*}{\multicolumn{2}{|c|}{$\begin{array}{l}\text { d'actifs } \\
\text { (millions de } \\
\text { personnes fhine }\end{array}$}} & 46,74 & 46,69 & 45,64 \\
\hline & & 602,22 & 699,57 & 737,40 \\
\hline & & 1993 & 1998 & 2002 \\
\hline \multirow{3}{*}{\multicolumn{2}{|c|}{$\begin{array}{l}\text { Populationord-Est } \\
\text { (milliong de } \\
\text { personnesthine }\end{array}$}} & 102,37 & 105,74 & 107,15 \\
\hline & & $1.185,1$ & $1.248,1$ & $11.284,5$ \\
\hline & & 1993 & 1998 & 2002 \\
\hline \multirow{2}{*}{$\begin{array}{l}\text { Actifs/ } \\
\text { Populati } \\
\text { (en } \% \text { ) }\end{array}$} & Nord-Es: & $45,66 \quad 8$ & $44,15 \div$ & $42,59:$ \\
\hline & Chine & 50,81 \& & 56,05 & $57,41 \%$ \\
\hline
\end{tabular}

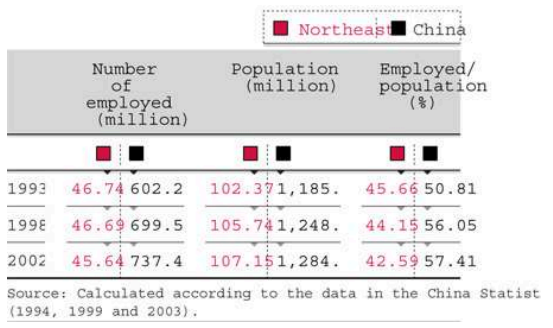

The SOEs still dominate

On the one hand, the non-state-owned enterprises have developed slowly, while the SOEs are in difficulty. In the 1998-2001 period, the ratio of state-owned to the region's industrial output value changed little. However, most state-owned enterprises became state-holding enterprises. In 2001, state-owned or holding enterprises contributed 73.27\% of the region's total industrial output value, 28.84 percentage points higher than the nation's average (Table 5). This means the non-state sector is too weak in the region in terms of both output value and provision of jobs. In this situation, the redundant workers of the state-owned sector have few outlets and the whole economy lacks vitality.

5. The status of state-owned enterprises in the northeast

\begin{tabular}{|c|c|c|c|}
\hline & $\begin{array}{l}\text { State-owned } \\
\text { industrial enterpribes }\end{array}$ & $\begin{array}{l}\text { State-owned and bolding } \\
\text { industrial enterprises }\end{array}$ & $\begin{array}{l}\text { Assets liabilit } \\
\text { of state-owned } \\
\text { industrial enterp }\end{array}$ \\
\hline & $1998: 2001$ & 19982001 & $1998 \quad 2001$ \\
\hline Liaching & 53.6022 .30 & $66,7265,37$ & 66.72 .60 .61 \\
\hline Jilin & 66.8336 .08 & 80.6580 .30 & 73.5368 .34 \\
\hline Hetlongfiang & 65.3317 .02 & 63.2882 .74 & 69.1478 .43 \\
\hline Northeast & $59,5923,84$ & $74,2273,27$ & $69,0366.65$ \\
\hline China & $34+10.18 \cdot 05$ & 49.63 .44 .43 & 65.9462 .70 \\
\hline
\end{tabular}

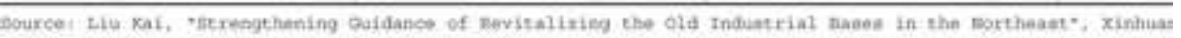

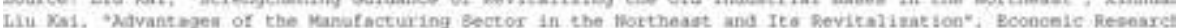

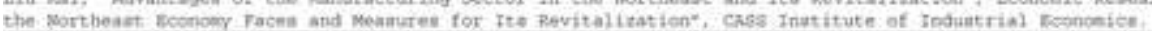

Cities dependent on mineral and forest resources are struggling

The ratio of miners and loggers to the total industrial workers is between $1 / 7$ and $1 / 6$ in the region, far higher than the national average and also higher than the resource- 
rich western region. The reserves of Heilongjiang province's four largest coal mines (Heguang, Jixi, Shuangyashan and Qitaihe) are almost out, and 11 of Liaoning province's 35 key coal mines will be used up and closed in ten years. Compared to 1993, the number of miners and loggers in the region decreased by $52 \%$ in 2002. For the same period, the national figure was $40 \%$. The reduction has resulted in serious social problems.

Residents' incomes decreased

In the last decade, urban residents net incomes have been below the national average and showed a downward trend until 2000 (Table 6). Of the three provinces in the region, Liaoning saw the largest drop from $96.17 \%$ of the national average in 1992 to $84.70 \%$ in 2002. Although the range of decreases in Jilin and Heilongjiang was narrower until 2001, the real gap to the national average was greater, with a 2002 index of about $80 \%$.

6. Northeast resident per capita net income compared to the national average

\begin{tabular}{|c|c|c|c|c|c|c|c|}
\hline & 1992 & 1995 & 1998 & 1999 & 2000 & 2001 & 2002 \\
\hline Liaoning & 96,17 & 86.54 & 85.11 & 83,68 & 85.32 & 34.51 & 84.70 \\
\hline Jilin & 80.77 & 74.13 & 77.54 & 76.53 & 76.59 & 77.85 & 81.27 \\
\hline Heilongjiang & 80,44 & 78.31 & 78.68 & $76=50$ & 78,23 & 79.10 & 79.92 \\
\hline China & 100 & 100 & 100 & 100 & 100 & 100 & 100 \\
\hline
\end{tabular}

In 1993, growing one hectare of maize yielded between 5,000 and 6,000 yuan. By 2001, this figure dropped to 100 or 200 yuan. Therefore, the region's farmers, whose net income was higher than the national average in the early 1990s, suffered a sliding standard of living. By 2000, Jilin and Heilongjiang farmers' net income was already below the national average (Table 7). In the last two or three years, although the farmers benefited from the upward reversal in the prices of agricultural products, their net household income remained well below the national average.

Share of invested capital insufficient for renewal of assets

The investment in the region should be analysed from two angles: on the one hand, the share of the region's investment in the fixed assets of the national total has increased from $7.95 \%$ in 1998 to $8.29 \%$ in 2001 . This partly shows that before launching the new drive, the central government had tried to help the region. On the other hand, compared to the share of the region's assets and GDP in the national total, the investment in the fixed assets in the region remains small. This directly affects the enterprises' renewal of assets. Hence the region's level of upgrade of 20 branches of the manufacturing sector's 29 dropped from 1998 to 2001. These 20 branches contributed $59.75 \%$ of the region's total industrial output value and $77.69 \%$ of the manufacturing sector's total output value in $2001^{6}$.

The latest drive: what's new and specialRedefining the government's role

As a national development strategy, the effort to revitalise the northeast will receive the central government's policy guidance and support, but the issue is how the policy inputs can be transformed into the region's own initiative for reform. In other words, is the region prepared to rely on market or policy? Related to this, it is vital to redefine the role of government. China's planning system originated in this region and today the region remains more under its sway than others. If using the annual average figure of the region's investment in industrial technological renovation and renewal for the 
1996-2000 period and if the current practice of depending mainly on government investment was to continue, it will take thirty years for Jilin province alone to renew the fixed assets of the existing industrial enterprises. It would take developed countries no longer than ten years. In this regard, clearly defining the role of the government and the market is tremendously important.

Influenced by the previous planning system, enterprises and governments in the region are short on motivation and ability for self-renewal. By the 1980s, serious problems became evident in the region: ageing industrial technologies, outdated equipment and products, and the heavy social burden the enterprises carried. The central government has since provided support to the renovation and renewal of the old industrial bases in the region. Of them, three important means were financial, loan and investment policy supports. Since the Ninth Five-Year Plan period (1996-2000), the central government has applied policies of turning debt into shares, cancelling bad loans, resorting to the national debt to stimulate domestic consumption, and interest subsidies to technical renovation loans. These policy measures had been modestly effective. As a result, the region's state-owned sector ration in terms of its whole economy increased as was that of the manufacturing sector in all industry.

But this time, the central government is placing the emphasis on encouraging the region to facilitate the structural and institutional renewal rather than simply continue the old practice of providing funds or preferential policies. More specifically, the structural and institutional renewal requires, on the one hand, getting rid of the last stronghold of the planning system and fostering the growth of market forces, while creating the conditions for the growth of the non-state sector and actively seeking foreign investment. These are believed to be key to the success of the current efforts to revitalise the region ${ }^{7}$.

7. Northeast rural household per capita net income compared to the national average

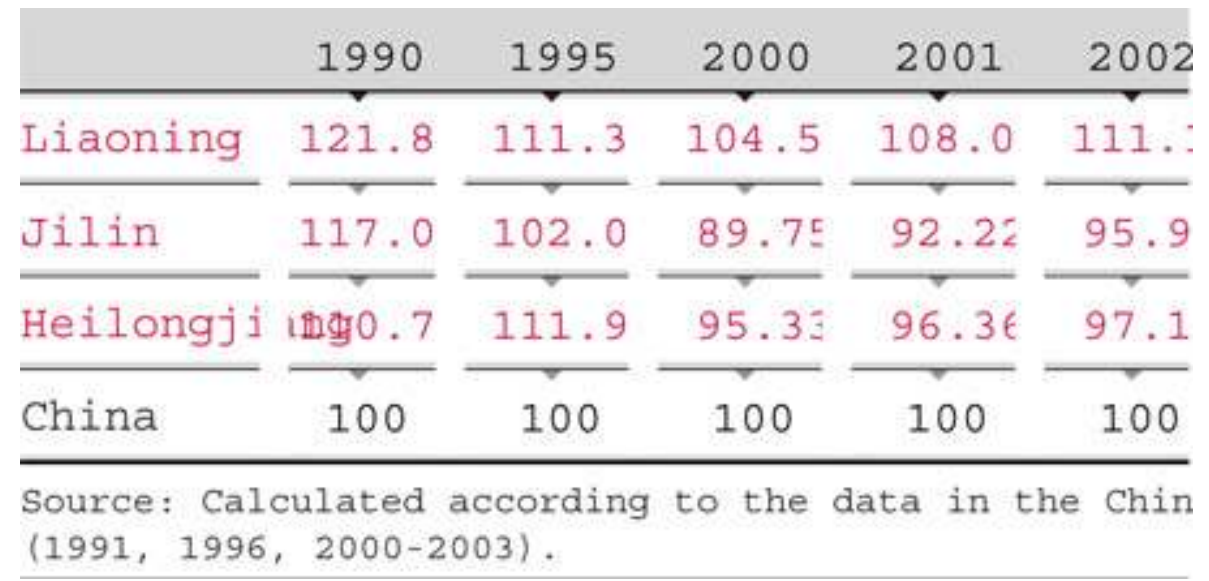

21 Related to this, Premier Wen Jiabao elaborated on the guiding principles, as the region must rely on its own strength. When providing necessary support in terms of policy and funds, the state should also respect market rules and pursue returns. Fewer new projects and development zones should be considered. Instead, efforts should be devoted to reforming existing enterprises, making comprehensive and co-ordinated use of existing resources, and increasing the efficiency of the key elements of production ${ }^{8}$.

Division of labour between central and local government 

whole region? Is the priority to launch reforms or inject money? Is it best to tackle the system of enterprises or the administrative area? Many believe the answer is obvious: it is more advisable to create a new market system outside the existing system poisoned by the planning mentality and practices. Hence the proposal for upgrading Shenyang to a central government directly administered municipality. The performance of Chongqing Municipality gives credit to this proposal. Shenyang boasts the best infrastructure of heavy machine-building in the region and many SOEs concentrate there ${ }^{9}$.

Premier Wen said in May 2004 the central government had "worked out relevant policies, principles and plans of action" ${ }^{10}$ The complete document is not yet available. However, two months earlier, he unveiled four major tasks for reinvigorating the industrial rustbelts for 2004, promising more efforts to restructure state firms, promote the private sector, optimise the industrial mix, and absorb more domestic and overseas investment. The region is urged to speed up institutional innovation and reform-apparently the main road to their revitalisation. Reform of the state-owned assets management system and SOEs must be deepened to increase economic vitality, 
and efforts should be made to promote the mixed ownership and private sectors of the economy. Optimising the existing industrial mix and upgrading its technology is key to revitalisation of the once-influential industrial bases. The traditional industrial bases should continue to develop those sectors that are well-adapted pillar industries, and strive to advance modern agriculture and consolidate its position as major grain producers and suppliers. They should continue to open their economies to other parts of the country and to the world. Governments in the region are encouraged to expand employment and provide better social security coverage. It is essential to transform the mode of economic growth and prevent irrational investment and duplication of construction projects involving low-level technologies ${ }^{11}$.

These are general guidelines. A synthesis of limited publicly available information can only provide some clues to the more detailed or specific policies. It has been proposed that the central government may consider designating the northeast an experimental region for the delegation of the power of examination and approval over such matters as investment by non-state enterprises and foreign businesses, new projects and landuse rights. The purpose is to increase local autonomy, accelerate the transformation of government functions, and improve administrative efficiency by reducing or simplifying the examination and approval items or procedures.

The State Council has launched a pilot programme to reform the VAT system in the region to promote capital investment and technical upgrades. Companies in eight industries such as machinery, petrochemicals, shipping and vehicles are exempt from VAT on purchases of equipment and machinery backdated to July 1st 2004. Experts estimate that the pilot programme will reduce tax revenue for central and local government by as much as 15 billion yuan ${ }^{12}$.

The State Council announced in March 2004 that Jilin and Heilongjiang provinces were to be the only two experimental areas for the abolition of agricultural taxes. The lost local revenue will be covered by transfer payments from the central government. According to press reports, the Jilin and Heilongjiang farmers will be relieved of annual taxes amounting to 1.4 billion yuan and 2.82 billion yuan respectively. Or each farmer will be waived 100 yuan and 153 yuan respectively. Heilongjiang province has decided to change the role of the existing agricultural tax collectors to issuing government subsidies to farmers. The province has 4,000 such collectors at the township level and 500 at the provincial, municipal and county levels. According to an official of the Heilongjiang Provincial Finance Department, the direct subsidies provided by the province for 2004 are expected to total 1.85 billion yuan ${ }^{13}$.

The region needs to continue the adjustment of ownership composition to shrink the state-owned sector while expanding the non-state sector. This strategy, termed stimulating the reform of the existing scale of economy (yi zengliang cu cunliang de gaige zhanlüe) has proved effective in the coastal regions in southeast China. Development of the non-state sector in the region will not only create new employment opportunities for the workers laid off by the SOEs, but also spur the latter to improved efficiency through shedding redundant workers, thus strengthening the competitiveness of the SOEs.

The central government is being asked to increase transfer payments to the region, especially subsidies to unemployed workers. Statistics show that in five years, by 2002, the central government had injected 210 billion yuan from funds raised as national debt to the western region, making up $35 \%$ of total funds raised as national debt. It will 
be difficult for the central government to do the same for the northeast. Thus it is proposed that increased transfer payments to the region should come from the state budget.

41 A recommendation is being made to the central government to designate the northeast as an experimental region for reform of the investment and banking system to improve the environment for attracting investment both domestic and foreign. For the Chinese investments, the main target is the capital of the non-state sector. Utilisation of capital from outside the region is believed to be a key measure of the revitalisation drive. However, the reported opening of the new Northeast Revitalisation Bank in August 2004 has been postponed for one or two years ${ }^{14}$. The bank is to be established by reorganising the profitable Shenyang Commercial Bank. Registered capital of the bank will be increased to 3 billion yuan (US\$361 million) through issuing new shares, of which the state-owned stake will amount to 250 million yuan (US\$36 million). Private and international investors are all encouraged to take part ${ }^{15}$.

The central government is advised to annul the bad loans of the local branches of the four state-owned banks as a way of improving the region's investment environment. An "asset and liability exchange centre" can be set up in the region. The People's Bank of China has designed plans to deal with the heavy debt of enterprises, including turning the debts into shares, reducing or waiving interest of debts, postponement of mature debts and hanging up the debts.

The central and local governments can jointly create a fund for the renovation and renewal of the enterprises in the region to relieve the burden of the local government and the enterprises themselves. The State Development and Reform Commission had by July 2004 approved only two batches of investments for 160 renovation and hightech application projects in the region. They are valued at 66.6 billion yuan (US $\$ 8.06$ billion). Observers attributed the relatively small amount and delayed announcement of the second batch to a re-consideration of the old practice of "selecting projects and providing funds" to support a given region. In addition, 15 projects have been launched to handle the sinking zones from coal mining ${ }^{16}$.

Some scholars have suggested that central government aid should focus on supplementing the shortfall in the region's pension and unemployment funds. On the basis of the reforms introduced so far, the region began implementing the new "experimental methods of social security" last year, which apply the social security policy of Liaoning province to Jilin and Heilongjiang provinces. Under them, enterprise contributions to pension funds is reduced to $1.25 \%$ while that contributed by central finance has increased to $3.75 \%$ since 2004 . The workers themselves contribute another $5 \%{ }^{17}$.

45 The relevant policy papers place the priority on creating jobs. This should be a central element of any plans to revitalise industry. The labour intensive industries, small and medium-size enterprises and non-state-owned enterprises should be developed to absorb labour. The international experience can be learned in terms of providing incentives to creators of jobs, subsidising labour costs and reducing or waiving taxes for job creators. Special attention should be paid to resource-dry cities in implementing such a policy.

On regional economic co-operation, the northeast is urged to place emphasis on creating and expanding both domestic and foreign markets. The three provinces of the region should formulate an economic co-operation framework and co-ordination 
mechanism to promote regional integration. They should also strengthen co-operation with Japan, South Korea and Russia and make better use of the North-East Asian market.

Local responses and measuresLiaoning province

According to the Secretary of the Communist Party of China (CPC) Liaoning Provincial Committee, Wen Shizhen, the priority is structural adjustment, especially strengthening of the backbone enterprises, to turn the province into a national or international equipment manufacturer and an important raw material supplier. The aim is to realise basic industrialisation by $2010^{18}$.

The province has decided to consolidate three pillar industries: petrochemicals, iron and steel, and equipment manufacturing. Other measures include: facilitating the economic development of the county seats to stimulate rural economic development; speeding up the development of a modern service industry and upgrading its quality; encouraging the creation of new industries and light industry while helping the application of information technology to traditional industry.

The potential market for the province's equipment is very large. Currently many advanced enterprises in south China import equipment from North America and Europe. The main problem with Liaoning's equipment manufacturing sector is that enterprises are large but the volume of scale-end products is small. Enterprises tend to occupy a large area with large workshops, numerous machines and workers. But the degree of division of labour among enterprises in the same industry is low. Each factory produces almost all parts of a product, leading to small-scale production but high-cost end products. Taking the automobile industry as an example. Advanced mainframe plants and engine plants co-exist with backward parts plants. The industrial structure must be adjusted and maximised. The mainframe plants should be taken as the core with a number of parts plants as its suppliers. Turning the equipment industry into a major and strong sector requires many specialised medium-size and small factories. The role of high technology in transforming traditional industry cannot be overestimated.

50 In the past nine years, Anshan Iron and Steel Complex spent 16 billion yuan on technological renewal, freeing it from the 1950s or 1960s and upgrading it with late twentieth or early twenty-first century technology. According to Wang Jie, fellow of Chinese Academy of Engineering, China now possesses the most advanced technology of the metallurgical industry in the world, leading Japan and South Korea. The goal of the Complex is to be among the world's largest iron and steel manufacturers in five years. To this end, the province's two top iron and steel producers in Anshan and Benxi are negotiating reorganisation and merger.

Jilin province

51 Wang Yunkun, Secretary of CPC Jilin Provincial Committee, has presented a comprehensive plan ${ }^{19}$. While upgrading and maximising its secondary industry, the province will also develop modern agriculture and tertiary industries. In order to correct the imbalance between heavy and light industries, the province will encourage the development of processing of agricultural produce and pharmaceuticals.

The province's advantages remain in the manufacturing sector. By 2010, the annual sale of vehicles is projected to value 320 billion yuan with added value amounting to 100 billion yuan. The annual sales of the petrochemical industry will total 100 billion yuan with an annual growth of $12 \%$. Deep processing of maize, soybean, stock and 
poultry together with green food produced in Changbai Mountain will yield 200 billion yuan annually with an annual growth of $18 \%$. The modern production of traditional Chinese medicine, using herbal resources from Changbai Mountain, and biopharmaceuticals will turn in an annual 50 billion yuan with an annual growth of $20 \%$. Annual sales of the high-tech industry are expected to exceed 180 billion yuan. In tertiary industry, tourism has good potential, but it is too early to make it a pillar. The task now is to create and publicise the province's image, the focus of which is Changbai Mountain.

53 The key is to build up the initiative for economic development by eliminating institutional impediments. The mixed ownership sector with state-owned, collectively owned and non-state-owned capital should be fostered. Shareholding should be the main form of public ownership, which is of particular significance to the province with predominantly state-owned industries. The development of a capital market is a solution to the province's shortage of monetary capital. While local commercial banks and other banking institutions should be encouraged to set up and expand, banking institutions from other parts of China and abroad should be attracted, Wang stresses.

The province must open up more widely to domestic and overseas markets. Huang Ju, Member of the Politburo Standing Committee and Vice Premier, said during his inspection tour to the province last year: the drive to revitalise the northeast is a "banner" and an "international banner" ${ }^{20}$. What the region lacks in the vital elements of production it must make up using outside resources for its own development. Jilin will improve the methods of attracting foreign investors and pursue the results in order to make it a hot spot for investors. At the same time, the province will encourage local enterprises to expand their activities overseas. Cross-border trade with Russia, Japan, South Korea, North Korea and Mongolia should be developed. The governmentdominated opening up should be replaced by joint participation of government and social forces. The opening field should be enlarged from the manufacturing sector to all industries from agriculture to services as well as to the fields of science and technology, education, culture and public health, according to Wang.

The province will devote great efforts in developing non-state sector. A prerequisite is to create a culture and environment that will encourage business start-ups. The current culture is laden with commandeering and laziness fostered by the planning system. In 2001, the national average figure of private businesses per 10,000 was 9.32 while Jilin's was only 3.41. The investment made by the non-state sector made up $45 \%$ of the total social investment in China. But this figure was less than $10 \%$ for Jilin. In order to spur the development of non-state sector, which is vital to the success of the revitalisation drive, Wang promised, the government will abolish all regulations and policies unfavourable to the non-state sector. All investment fields from which state laws do not explicitly exclude the non-state sector should be opened. The non-state sector should be encouraged to participate in the reorganisation and renovation of the SOEs. Public works and infrastructure projects should also open to them.

Heilongjiang province

According to Song Fatang, Secretary of the CPC Heilongjiang Provincial Committee, in the next three years, the situation of the industrial sector will improve further with the accomplishment of reorganisation and renewal of the SOEs managed by local government, the consolidation of the social security system, and accelerated development of new industries in resources-dry cities ${ }^{21}$. The provincial targets include: 
to keep the registered urban unemployment rate within $5 \%$, curb the tendency towards a worsening of the eco-environment, and a greater than $10 \%$ annual increase in industrial output value or a more than 9\% increase in GDP. The province's GDP in 2000 will be doubled by 2008 .

The province has chosen the following five main industries as its priority: equipment manufacturing, petrochemicals, energy, green and special food production, and pharmaceuticals.

Investment opportunities for overseas investors?

A Singapore-based company, GT Tyre?. (China) Investment Co., Ltd., purchased a oncefamous tyre? manufacturer named Hualin in Heilongjiang province in July 2003, becoming the first foreign firm to buy a state-owned company through auction, successfully winning $44.43 \%$ stock equity ${ }^{22}$.

During his visit to London in May 2004, Premier Wen invited British entrepreneurs to take part in the revitalisation of China's traditional industrial bases so as to open up new areas of Sino-British economic co-operation. He said the British business community could "give full play of their advantages in capital, technology and management." They could create joint ventures and corporations in the region, he added $^{23}$. In March 2004, the Chinese Ministry of Science and Technology organised for diplomats from 15 member states of the European Union a tour to the three northeast provinces. The purpose was to promote the strategy of revitalisation through science and technology by seeking international co-operation ${ }^{24}$. In the same month, a sixmember delegation of science and education officials from Germany visited Heilongjiang province. They exchanged views with local officials on the possibility of co-operation in the fields of equipment manufacturing, deep processing of energy resources, material science, equipment serving, environmental protection and training of engineers and technicians. A member of the delegation said the German government and scientific institutions hoped that the bilateral enterprise-to-enterprise cooperation in the economic and technological fields would be promoted, so that science and technology could contribute to the rejuvenation of the region. Germany was also willing to support the northeast region in training technical workers ${ }^{25}$.

Bo Xilai, then Governor of Liaoning province, told a media delegation from Hong Kong in summer 2003 that Hong Kong businessmen could participate in the construction of an equipment manufacturing base and raw materials base. They could also have involvement in the reorganisation of the medium and small enterprises centred on converting them into share-holding companies ${ }^{26}$.

61 The region has recognised that the private and foreign businesses are vital to its efforts to rejuvenate. The local governments are considering relaxing the current regulations on the access to market, permitted investment fields, import and export credit guarantee and taxation. A notable change is that they are now willing to make available enterprises with good assets or satisfactory performance to private and foreign investors. Except for military, petroleum, petrochemical and power-generating industries, the state sector will withdraw from the regular competitive fields. Foreign investors can now enter many newly opened fields, including banking, hightechnology, education, culture and public health.

62 The State Assets Regulatory and Management Commission announced in February 2004, about four hundred SOEs in northeast China will go bankrupt or be forced to merge in the next three to four years as part of a massive restructuring plan for heavy 
industry. The plan includes allowing more foreign and private capital to be placed into SOEs ${ }^{27}$.

Heilongjiang province has set up a state-level industrial park in the provincial capital Harbin. According to Wang Shihua, Deputy Mayor of the city, a series of policies have been drawn up so as to attract investment from both China and overseas, and 13 related local government departments will provide all-round services for the new park, ensuring a good investment environment. As a key project for the city's development, the industrial park has been given priority in Harbin's development plan. The new industrial park will be located in the city's Songbei District, with an area of $29.94 \mathrm{sq} \mathrm{km}$, including three sub-parks-Qianjin, Songpu and Wanbao. By March 2004, 11 investment agreements had been signed, involving 648 million yuan, and another 12 projects worth a total of 800 million yuan were under negotiation ${ }^{28}$.

Since the beginning of 2004, Liaoning has seen unprecedented numbers and high levels of foreign business fact-finding missions. There have been at least fifty large projects involving more than US $\$ 50$ million each under negotiation between foreign businesses and the province. In the first half of 2004, Shenyang Municipality alone approved 301 foreign-invested enterprises, with signed contracts valuing US $\$ 720$ million. Of the total, US $\$ 600$ million was foreign direct investment, a $180 \%$ increase over the same period last year ${ }^{29}$. In fact, Liaoning's increase margin was smaller than the other two provinces in the region in terms of contracted foreign investments in the first five months of 2004 over the same period last year. The whole region was doing remarkably well in this respect with Jilin and Heilongjiang provinces registering an increase of 2.86 times and 2.46 times that of the country as a whole.

BASF, one of world's largest chemical companies plans to invest in a new chemical project in the northeast, probably in Changchun, capital of Jilin province, one of the largest automobile industry bases in the country. Currently, there are two BASF-funded joint ventures in the northeast, in Jilin City, and in Shenyang, capital of Liaoning province. Currently, BASF-funded companies in China account for $5 \%$ of its total sales, but the rate is expected to top $10 \%$ by 2015 , not less than BASF companies in Japan ${ }^{30}$.

The northeast has recently become a focus of attention due to the central government's new policy aimed at its rejuvenation. Some commentators have termed it the "third northeast phenomenon" (WWWWWWW, di san ci dongbei xianxiang). In contrast to the first two painful "northeast syndromes", this time the term is used positively in the local hope this will be the starting point of a change for the better. However it is too early to judge whether the region will indeed become the fourth pillar of China's growth as expected. The quick results of the four Special Economic Zones at the end of 1970s and the development of Pudong in Shanghai in the early 1990s may not be repeated easily. Central leaders have cautioned that the new drive is similar to the Development of the West Programme, that it will be a long-term effort although local leaders have formulated plans that promise to deliver results in five or seven years.

A general lack of motivation and initiative for self-renewal and development is a serious problem in the region. Elimination of this last stronghold of China's planning system requires a transformation of the mentality of dependence on the central government and implementation of institutional reform. The key to the success of the new drive is for local government to allow the market to operate without undue control or interference rather than simply depending on central government preferential policy. 
Only one year after the launch of the new drive, the central government has provided considerable policy and fund inputs to the region, which has been designated as a pilot area for reforming the VAT system. Jilin and Heilongjiang provinces have become experimental areas for abolishing agricultural taxes. The plan to establish a new Northeast Revitalisation Bank has been approved although its opening has been delayed probably due to reconsideration of some practical issues. Some 160 renovation and high-tech application projects, valued at 66.6 billion yuan, have been provided. The central finance's contribution to the region's pension funds has been increased to $3.75 \%$ since 2004. Important indicators to judge the performance of local officials will be how and whether the non-state sector will grow and whether the overseas investors will stay while more will come.

\section{NOTES}

1. The author would like to thank Professor Yang Dali for his comments on a previous version of this article.

2. State Council, "Notice on Some Policy Measures for Implementing the Drive to Develop the West", (State Council Document No. 33, 2000), in "Periods Prior to and After the Announcement of the State Policy of Revitalizing the Northeast", 21 Century Economic Reports, http://www.sina.com.cn (accessed on August 10th 2004).

3. Xinhua website, The Chinese Government Set Out to Privatize the Old Industrial Bases in the Northeast, August 14th 2003.

4. Xinhua website, "The State Council Leading Group of Revitalizing the Old Industrial Bases in the Northeast Region Holds its First Meeting", March 24th 2004; "Premier Wen Jiabao Takes Leadership of Revitalizing the Northeast", Europe-Asia News Weekly, http://www.ouya.hu/NewsVoP/N256N001.htm (accessed on October 7th 2004).

5. In the same period, the national figure dropped from $17.96 \%$ to $15.38 \%$.

6. See Liu Kai, "Strengthening Guidance of Revitalizing the Old Industrial Bases in the Northeast", Xinhuanet, Jilin Channel, (accessed on October 6th 2004); Liu Kai, "Advantages of the Manufacturing Sector in the Northeast and Its Revitalization", Economic Research References, Vol. 75, 2003; Liu Kai, "The Problems the Northeast Economy Faces and Measures for Its Revitalization", CASS Institute of Industrial Economics.

7. Chen Zhengrong, "Narration of and Comments on the 'Revitalizing the Northeast' Policy", Journal of Capital Market, No. 11, 2003, pp. 36-42.

8. Xinhuanet, "Wen Jiabao: The Revitalization of the Old Industrial Bases in the Northeast Must Adapt to the New Situation and March on a New Route", http:// www.sina.com.cn, August 5th 2003 (accessed on August 12th 2004).

9. "The Method of Revitalizing the Northeast should be Changed, Experts Propose for Upgrading Shenyang to a Municipality Directly Administered by the Central Government", Xinhuanet, May 9th 2004. 
10. "Visiting Chinese Premier Wen Jiabao delivers a speech at the opening ceremony of the Seminar on Revitalizing the Old Industrial Base in Northeast China in London", Xinhuanet, May 10th 2004.

11. "The State Council Leading Group of Revitalizing the old Industrial Bases in the Northeast Region Holds its First Meeting", People's Daily, March 24th 2004.

12. "Firms in Rust Belt Win Tax Break", South China Morning Post, September 21st 2004, p. A7.

13. "Jilin and Heilongiiang Are to Immediately Trial the Annulment of Agricultural Taxes", China Youth Daily, Zhongguo Jiangxi Wang, March 26th 2004 (accessed on October 4th 2004); "The Ministry of Finance Clarifies the Relevant Policies of Trials on Annulling Agricultural Taxes", Xinhuanet, April 15th 2004 (accessed on October 4th 2004).

14. "Establish the Financial Centre of the Northeast, the Northeast Revitalization Bank is Expected to be Operational in Shenyang by the End of the Year", www.runsky.com, September 21st 2004.

15. "New Bank Set to Revitalize Northeast China", China Daily, May 31st, 2004.

16. "The State Implements Four Policies to Support the Revitalization of the Northeast of China", Xinhuanet, September 29th 2004.

17. Ibid.

18. "Party Secretaries of Three Northeast Provinces Talk About Revitalization, Which Requires New Measures", Xinhuanet, October 12th 2003.

19. Wang Yunkun, "Speech at the Meeting on Revitalizing the Old Industrial Bases", in Structural Reform (Renmin University Photocopies of Press and Journal Materials), No. 3, 2004.

20. Ibid (quoted by Wang Yunkun).

21. "Party Secretaries of Three Northeast Provinces Talk About Revitalization, Which Requires New Measures", Xinhuanet, October 12th 2003.

22. A Singapore Company Gets Holding of GT Tire, http://www.ctrrr.com/index.html, October 6th, 2004.

23. "Premier Wen welcomes UK businesses to join China's industrial revitalization", Xinhuanet, May 10th, 2004.

24. "Diplomats from 15 Member States of the European Union Visit the Old Industrial Enterprises in Shenyang", Xinhuanet, March 25th 2004.

25. "Germany seeks co-operation opportunities in Heilongjiang", Xinhuanet, March 30th 2004.

26. Xinhua Website, "100 billion capitals from the non-state sector in south China flow into Shenyang and Bo Xilai call for re-entering Northeast", August 8th 2003.

27. "Mass Restructuring Planned for 400 SOEs in Northeast China", China Daily, February 15th 2004.

28. "Harbin to Build New Industrial Park", Xinhuanet, January 7th 2004.

29. "Liaoning Becomes An Investment Hot Spot with Visits of Foreign Business Factfinding Missions One Followed by Another", http://www.sina.com.cn, June 21st 2004.

30. “Chemical giant eyes China's development programs", Xinhuanet, April 22nd 2004. 


\section{RÉSUMÉS}

In 2003, the Chinese government made revitalising the northeast a priority, a clear sign that the ailing region can no longer be ignored. In the early 1990s, the region found it particularly difficult to adapt to the structural reforms and the country's transition from a planned to a market economy. Industry and agriculture touched on crisis. Increasing numbers of officials and scholars agree that the northeast should have open, transparent and uniform rules of market operation, rather than funds, preferential policies and publicity drives. It has been proposed that the central government may consider designating the northeast an experimental region for the delegation of powers of examination and approval over such matters as investments by non-state enterprises and foreign businessmen, the starting of new projects and land-use rights. 